\title{
KLRG1 wt Allele
}

National Cancer Institute

\section{Source}

National Cancer Institute. KLRG1 wt Allele. NCI Thesaurus. Code C123854.

Human KLRG1 wild-type allele is located in the vicinity of 12 p13.31 and is approximately $108 \mathrm{~kb}$ in length. This allele, which encodes killer cell lectin-like receptor subfamily G member 1 protein, is involved in the modulation of T-lymphocyte and natural killer cellmediated immunity. 